\title{
Gypsiferous mine water use in irrigation on rehabilitated open-cast mine land: Crop Production, soil water and salt balance
}

\author{
J.G. Annandale ${ }^{\mathrm{a}, *}$, N.Z. Jovanovic a, J.J.B. Pretorius ${ }^{\mathrm{a}}$, S.A. Lorentz ${ }^{\mathrm{b}}$, \\ N.F.G. Rethman ${ }^{a}$, P.D. Tanner ${ }^{\mathrm{c}}$ \\ a Department of Plant Production and Soil Science, University of Pretoria, Pretoria 0002, South Africa \\ b Department Agricultural Engineering, University of Natal, Private Bag X01, Scottsville3209, South Africa \\ c Anglo Coal Environmental Services, Private Bag X9, Leraatsfontein1038, South Africa
}

Accepted 19 August 2000

\begin{abstract}
The use of gypsiferous mine water for irrigation of agricultural crops is a promising technology, which could alleviate a shortage of irrigation water and address the problem of disposal of mine effluent. A field trial was established at Kleinkopje Colliery in Witbank (Mpumalanga Province, South Africa) during the 1997-1998 season. Sugar beans and wheat were irrigated with three center pivots, on both virgin and rehabilitated land. The objectives were to determine crop response to irrigation with two types of mine water, to determine the impact of irrigation with inferior quality water on virgin and rehabilitated soil, and to collect atmospheric, crop and soil data for detailed validation of the soil water balance (SWB) computer model. Crop yields were generally satisfactory. Yield of sugar beans on rehabilitated land was low compared with virgin land, probably due to the late planting date, hail damage and soil compaction. SWB simulations were compared with field measurements of weather, crop growth, water and salt balance parameters. Both field measurements and model simulations indicated an increase in soil salinity, with limited drainage and salt leaching. Long-term simulations of the water and salt balance were carried out with SWB to predict the long-term sustainability of irrigating with gypsiferous water. (C) 2001 Elsevier Science B.V. All rights reserved.
\end{abstract}

Keywords: Crop growth; Environmental impact; Gypsiferous mine water; Irrigation; Mathematical modelling; Soil salinity; Sugar beans; Waste disposal; Wheat

\footnotetext{
* Corresponding author. Tel.: + 27-12-4203223; fax: + 2712-4204120.

E-mail address: annan@scientia.up.ac.za (J.G. Annandale).
}

\section{Introduction}

Disposal of mine wastewater is a world-wide problem occurring wherever coal and gold mines as well as old underground workings are found (Pulles et al., 1995). There are, of course, different 
types of water emanating from mines, depending largely on the geological properties of the coal, gold ore and other geological material with which water comes into contact. Such water could result in salinization of soils, rivers, dams and catchment areas, if freely discharged into the natural environment. Current measures to prevent pollution of the environment include (i) prevention of ingress of water into the working by grading the surface area around the mine or building channels to collect and divert stormwater; (ii) establishment of vegetation on tailing dumps and dam surfaces to prevent erosion, reduce the quantity and improve the quality of rainfall run-off from dump sites; (iii) storage of mine water in evaporation areas; (iv) recycling of water from tailing dams through gold-recovery plants; and (v) utilization of mine water for cooling and by selected industries which can tolerate low quality water (Pulles et al., 1996). In several mines, acid mine drainage is treated with hydrated lime $\mathrm{Ca}(\mathrm{OH})_{2}$ in order to neutralize acidity (Van Staden, 1979). Most of the resulting $\mathrm{CaSO}_{4}$ is precipitated in sedimentation basins, but the liquid effluent is saline and gypsiferous. This wastewater is then used for dust alleviation on gravel roads and for irrigation of lawns.

The coal fields of the Eastern Highveld region of South Africa underlie one of the most important high-potential agricultural areas in the country. This is of particular significance when viewed against the fact that South Africa has a very low percentage of arable land, of which only a third (4.5 million ha) is regarded as being of high potential. In addition, South Africa has a low and variable rainfall and $66 \%$ of the country is classified as semi-arid to arid. In view of the steadily increasing population, it is vital that agricultural land be maintained and effectively utilized.

The use of gypsiferous mine water for irrigation of agricultural crops is a promising technology which could solve problems related to both the shortage of irrigation water and the disposal of effluent mine drainage (Du Plessis, 1983; Barnard et al., 1998). Large amounts of wastewater could possibly be utilized for irrigation of high-potential soils on the Highveld. In this summer rainfall region, dry-land winter cropping is not feasible and mine water is often the only source of water for irrigation. Moreover, concentrating the gypsiferous soil solution through evapotranspiration, thereby precipitating gypsum in the profile, could limit environmental pollution. Contamination of downstream water supplies for other users could also be reduced, and additional income could be achieved through farming.

Jovanovic et al. (1998) showed that gypsiferous mine water could be an additional resource for agriculture, particularly where prolonged drought periods are likely to occur. They also recommended high-frequency irrigation and careful fertilization practices to provide crops with the right amounts of available soil water and nutrients throughout the growing season. The objectives of this work were to determine crop response to irrigation with gypsiferous mine water on a commercial field scale, and the impact that this water would have on virgin and rehabilitated soil. A further objective was to collect atmospheric, soil and crop data for detailed validation of the soil water balance (SWB) computer model (Annandale et al., 1996a; Barnard et al., 1998) to be used for long-term predictions of the water and salt balance.

\section{Materials and methods}

A field trial was established at Kleinkopje Colliery, close to Witbank (Mpumalanga Province, South Africa). The climate of the region is one of summer rainfall with an average of about 700 $\mathrm{mm} / \mathrm{a}$. Three center pivots have been set up for irrigation with mine water, on fields referred to as Major, Jacuzzi and Tweefontein. The pivot at Major irrigates 30 ha of virgin soil, predominantly Clovelly and Avalon (Soil Classification Working Group, 1991), or Plinthic Cambisol and Ferralsol (FAO, 1998), whilst pivots at Jacuzzi and Tweefontein irrigate 20 ha of rehabilitated land each. Free percolation of water is limited by an underlying layer of weathered sandstone with some plinthic formations in the profile of the virgin soil (generally between 0.5 and $1.1 \mathrm{~m}$ depth), and the spoil layer on rehabilitated land (generally at $0.9 \mathrm{~m}$ depth). The $\mathrm{pH}\left(\mathrm{H}_{2} \mathrm{O}\right)$ of reha- 
bilitated soil ranges from 4.21 to 5.38 , whilst bulk densities are from 1.4 to $1.83 \mathrm{Mg} / \mathrm{m}^{3}$ for the top soil, and from 1.82 to $1.94 \mathrm{Mg} / \mathrm{m}^{3}$ for the spoil layer.

Major field was planted to sugar beans (Phaseolus vulgaris) during the 1997-1998 summer season. Half of the field was planted to cv. Pan 148 on 27 November 1997, and the other half to cv. Kranskop on 3 December 1997. Row spacing was $0.9 \mathrm{~m}$ and seeding density was $70 \mathrm{~kg} / \mathrm{ha}$. Based on soil analytical results indicating low content of magnesium $5 \mathrm{Mg} / \mathrm{ha}$ dolomitic lime and $300 \mathrm{~kg} / \mathrm{ha}$ superphosphate $(10.5 \% \mathrm{P})$ was broadcast and incorporated to a depth of $0.2 \mathrm{~m}$ before planting. At planting, $250 \mathrm{~kg} /$ ha 3:4:3 (20) liquid fertilizer was applied, and Preecede with active ingredient metazachlor was sprayed to control broad leaf weeds and grasses. A $20 \mathrm{~m}$ wide strip was planted outside the field to allow crop growth and soil water to be monitored under dry-land conditions. Half of Jacuzzi field was planted to sugar beans (cv. Kranskop) on 6 January 1998 and the remaining half with problematic drainage was planted to an annual pasture crop (Eragrostis tef cv. SA Bruin) on 2 February 1998. Tweefontein field was planted to sugar beans (cv. Kranskop) on 9 January 1998. Based on soil analytical results, $3 \mathrm{Mg} /$ ha calcitic lime was applied on the Jacuzzi and Tweefontein fields before planting. Row spacing, seeding density, fertilization and weed control treatments were the same as those for Major.

After harvesting sugar beans, the fields were planted to wheat (Triticum aestivum) during the 1998 winter season. Half of each field was planted to cv. SST 825 , and the other half to cv. Kariega 103. Planting was between 24 and 30 June 1998. Both cultivars were planted at $150 \mathrm{~kg}$ seed/ha. Before planting, $120 \mathrm{~kg} /$ ha urea $(46 \% \mathrm{~N})$ and 200 $\mathrm{kg} /$ ha 3:4:3 (20) was applied. Urea was also topdressed at $100 \mathrm{~kg} /$ ha three times during the growing season at monthly intervals. No dry-land treatment was established during the dry winter season.

Each center pivot has six towers. Soil water status was monitored in the area irrigated from towers three and four by use of a neutron water meter (model CPN 503DR Hydroprobe, Camp- bell Pacific Nuclear, CA, USA), so that this 'doughnut' section of the field could be brought to field capacity (FC) by irrigation [mention of manufacturers is for the convenience of the reader only and implies no endorsement on the part of the authors or their sponsors]. Three irrigation regimes were implemented by adjusting the water delivery rate of the sprinkler nozzles. The nozzle package of the two pivot towers closest to the center of the field, was chosen to allow a higher delivery rate than for towers three and four, and this represented a leaching fraction (LF) strategy. The nozzles of the outer two towers were chosen to allow a lower delivery rate, and represented a deficit strategy. In this way, three areas with different irrigation regimes were achieved, namely (i) irrigations up to field capacity (FC strategy); (ii) irrigations with a leaching fraction applied (LF strategy); and (iii) irrigations below field capacity (deficit strategy). The quality of irrigation water was established from a sampling program for two water sources during the 1997-1998 season. Analytical results are summarized in Table 1.

An automatic weather station was set up at the Jacuzzi field, approximately $100 \mathrm{~m}$ from the outer tower of the center pivot. The location was surrounded by grass and was situated on a slight

Table 1

Average irrigation water composition during the 1997-1998 season

\begin{tabular}{lcc}
\hline Analyses & \multicolumn{2}{l}{ Field } \\
\cline { 2 - 3 } & Major and Jacuzzi & Tweefontein \\
\hline $\mathrm{Al}^{3+}(\mathrm{mg} / \mathrm{l})$ & 0.3 & 0.01 \\
$\mathrm{Ca}^{2+}(\mathrm{mg} / \mathrm{l})$ & 513 & 405 \\
$\mathrm{Mg}^{2+}(\mathrm{mg} / \mathrm{l})$ & 158 & 196 \\
$\mathrm{Na}^{+}(\mathrm{mg} / \mathrm{l})$ & 51 & 47 \\
$\mathrm{Fe}^{2+}(\mathrm{mg} / \mathrm{l})$ & 0.3 & 0.08 \\
$\mathrm{Mn}^{2+}(\mathrm{mg} / \mathrm{l})$ & 6 & 0.01 \\
$\mathrm{SO}_{4}^{2-}(\mathrm{mg} / \mathrm{l})$ & 2027 & 1464 \\
$\mathrm{Cl}^{-}(\mathrm{mg} / \mathrm{l})$ & 18 & 32 \\
$\mathrm{HCO}_{3}^{-}(\mathrm{mg} / \mathrm{l})$ & 143 & 68 \\
$\mathrm{TDS}^{\mathrm{a}}(\mathrm{mg} / \mathrm{l})$ & 2917 & 2212 \\
$\mathrm{pH}^{\mathrm{E}}$ & 6.4 & 7.0 \\
$\mathrm{EC}^{\mathrm{b}}(\mathrm{mS} / \mathrm{m})$ & 294 & 205 \\
\hline
\end{tabular}

a TDS, Total dissolved salts.

${ }^{\mathrm{b}} \mathrm{EC}$, Electrical conductivity. 
slope. The site was considered to be representative of the area where the three pivots were located. The following data were recorded - temperature and relative humidity using a CS-500 Vaisala temperature and humidity probe; solar radiation using an LI-200 pyranometer; wind speed using a R.M. Young cup anemometer; and rainfall amount and intensity, using a tipping bucket Texas Instruments Inc. rain gauge. Weather data were recorded every $10 \mathrm{~s}$, and processed daily with a CR10 data logger (Campbell Scientific Inc., Logan, UT, USA).

Representative sites for intensive monitoring of water and salt balance dynamics were set up in the three irrigation treatments of each field. The fields were not perfectly leveled due to the topographical characteristics. Areas as level as possible were chosen for the intensive monitoring sites in order to minimize surface run-off and lateral subsurface movement of water, and collect reliable data for the validation of the one-dimensional SWB model. Two access tubes were installed at each site for measurement of volumetric soil water content with the neutron water meter (NWM). Soil-water content was measured weekly, every $0.2 \mathrm{~m}$ down to $1.2 \mathrm{~m}$. Rainfall and irrigation amount and intensity were recorded with tipping bucket rain gauges connected to a CR10X data logger.

Soil samples were collected at the beginning of the trial from the intensive monitoring sites. The following parameters were determined for $0.2 \mathrm{~m}$ soil layers down to $1.2 \mathrm{~m}$ : bulk density, volumetric soil water content at -30 and $-500 \mathrm{~J} / \mathrm{kg}$ matric potential, concentrations of soluble $\mathrm{Ca}^{2+}$, $\mathrm{Mg}^{2+}, \mathrm{K}^{+}, \mathrm{Na}^{+}, \mathrm{NH}_{4}^{+}, \mathrm{SO}_{4}^{2-}, \mathrm{Cl}^{-}, \mathrm{NO}_{3}^{-}$and $\mathrm{CO}_{3}^{2-}$, concentrations of ammonium extractable $\mathrm{Ca}^{2+}, \mathrm{Mg}^{2+}, \mathrm{K}^{+}$and $\mathrm{Na}^{+}$, as well as Bray IP and $\mathrm{pH}\left(\mathrm{H}_{2} \mathrm{O}\right)$. These data were essential for the initial input of SWB, and for fertilization recommendations. At the end of the cropping seasons, soil water samples were sucked under vacuum with ceramic cup soil water samplers installed at 0.4, 1.0 and $1.4 \mathrm{~m}$ depths. These samples were analyzed for $\mathrm{Ca}^{2+}, \mathrm{Mg}^{2+}, \mathrm{K}^{+}, \mathrm{Na}^{+}, \mathrm{NH}_{4}^{+}$, $\mathrm{SO}_{4}^{2-}, \mathrm{Cl}^{-}, \mathrm{NO}_{3}^{-}, \mathrm{HCO}_{3}^{-}$and $\mathrm{CO}_{3}^{2-}$. The electrical conductivity of the soil solution was also determined.
Growth analyses involved the measurement of dry matter production of plant organs every 2 weeks, as well as leaf area index (LAI) which was measured with an LI-3100 (Li-Cor, Lincoln, NE, USA) belt-driven leaf area meter. Fractional interception of photosynthetically active radiation was measured weekly with a sunfleck ceptometer (Decagon, Pullman, WA, USA). The objective was to determine specific crop growth parameters for sugar beans and wheat using the procedures spelled out by Jovanovic et al. (1999).

\section{Model description}

SWB is a one-dimensional, daily time step, generic crop, irrigation scheduling model simulating the soil water and salt balance, as well as crop growth from specific crop growth parameters (Annandale et al., 1996a; Barnard et al., 1998). Water movement in the soil profile is simulated with a simple cascading model (Campbell and Diaz, 1988). Salt redistribution assumes complete mixing of irrigation and rainfall with the soil solution of the top soil layer, and similarly for the soil solution percolating to the next lower soil layer and so on. Precipitation and dissolution of gypsum and lime is determined using the approach of Robbins (1991). Critical assumptions of the chemical equilibrium model and the validation with lysimeter data were discussed by the same author (Robbins, 1991). Potential evapotranspiration (PET) is calculated as a function of daily average air temperature, vapor pressure deficit, radiation and wind speed, adopting the internationally standardized FAO (Food and Agriculture Organization of the United Nations, Rome, Italy) Penman-Monteith methodology (Smith et al., 1996). The two components of PET (potential evaporation and potential transpiration) are estimated using canopy cover (Ritchie, 1972). Water loss by evaporation is assumed to occur only from the top soil layer. Actual evaporation proceeds at the potential rate until the water content in the top soil layer reaches the permanent wilt percentage. Thereafter, it is equal to the product of potential evaporation and the square of the remaining evaporable water down to the air-dry 
water content (Campbell and Diaz, 1988). Actual transpiration is determined on a daily basis as either being limited by soil-water supply or evaporative demand (Campbell and Norman, 1998). Total soil-water potential is used to determine the amount of water available for crop transpiration in each soil layer. In the absence of specific ion toxicities and nutritional imbalances, the osmotic effect on crop growth is simulated by adding osmotic potential to the matric and gravitational soil-water potentials (Campbell, 1985). The effect of increased root resistance due to soil salinity (Jovanovic and Annandale, 1998) was excluded from these simulations. The daily dry matter increment is taken as the minimum of the transpiration-limited (Tanner and Sinclair, 1983) and radiation-limited dry matter production (Monteith, 1977), with water stress affecting the partitioning of assimilates to the different plant organs.

Required input data are - planting date, latitude, altitude, irrigation water amounts, concentrations of $\mathrm{Ca}^{2+}, \mathrm{Mg}^{2+}, \mathrm{Na}^{+}, \mathrm{K}^{+}, \mathrm{Cl}^{-}$and $\mathrm{SO}_{4}^{2-}$ in irrigation water, as well as weather data. In addition, volumetric field capacity, permanent wilting point, initial volumetric soil-water content and the content of ionic species are required for each soil layer. The SWB model is written in Delphi 4 (Inprise Corp.).

\section{Results}

\subsection{Crop response to irrigation with gypsiferous mine water}

Harvestable dry matter (HDM) production obtained for each field and treatment is summarized in Table 2. Harvestable dry matter includes pod plus seed in the case of sugar beans, and grain in the case of wheat. Although comparable yield data with good quality water are not available, the yield of sugar beans obtained under irrigation with mine water on virgin soil was comparable to yields registered in the area. Yields of sugar beans on rehabilitated land were, however, low compared with virgin land. The likely reasons were late planting date, soil compaction, low soil $\mathrm{pH}$
$\left(\mathrm{H}_{2} \mathrm{O}\right)$ and nutritional deficiencies. The center pivot at Jacuzzi also did not operate for large part of the 1997-1998 summer season due to mechanical and electrical problems as well as water logging. As a result, the crop suffered severe water stress. Hail damage also occurred at Jacuzzi during the vegetative stage of the crop. Excellent yields of wheat were obtained on both virgin and rehabilitated land. Wheat is reportedly more tolerant to soil salinity than beans (Maas, 1986). No symptoms of foliar injury due to sprinkler irrigation with gypsiferous water were noted on either crop.

The underlying layer in the profile of the virgin land, and the spoil layer on rehabilitated land prevented free percolation of water and leaching of salts. This caused ponding at specific sites during the rainy summer season, probably due to sub-surface drainage from higher areas of the fields. Losses of yield were experienced due to water logging in particular at Tweefontein.

\subsection{Seasonal simulations}

Daily weather data collected with the automatic weather station, average irrigation water qualities (Table 1), soil physical properties, as well as initial soil chemical properties were entered in the SWB database and used as model inputs. Soil-water deficit to field capacity determined from NWM measurements, and results of crop growth analyses were also entered in the SWB database and compared with simulations. Model simulations of crop growth, as well as the soil-water and salt balance were carried out for all intensive monitoring sites, in order to calibrate the model. An example is shown in Figs. 1 and 2 for sugar beans irrigated to $\mathrm{FC}$ at Major.

In order to predict the soil-water and salt balance accurately, it is essential to simulate crop growth and water use reasonably well. Fig. 1 presents measured and simulated root depth (RD), LAI, top dry matter (TDM) and HDM, as well as the soil-water deficit to field capacity. Parameters of the statistical analysis of measured and simulated data are shown in the top right corner of the output graphs. These were recommended by De Jager (1994) to assess the accuracy 


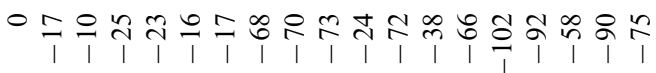

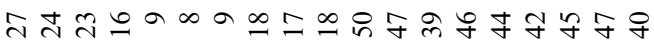

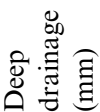

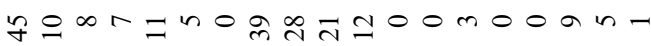

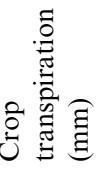

ஃ 总

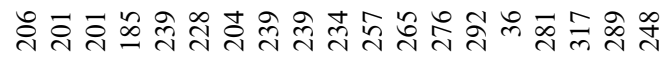

.$\tilde{5}$

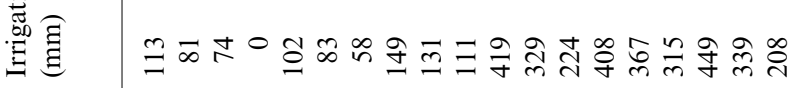

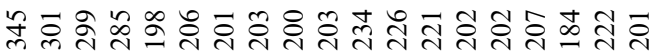

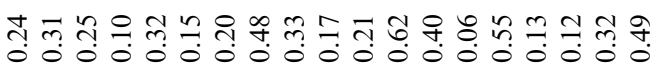

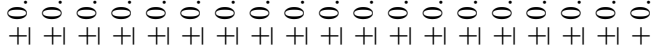
તิ

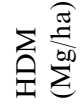

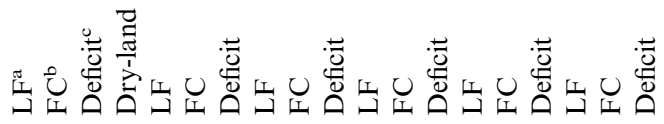
崖突 券 के 空. 过 .롤 施总

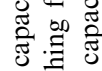
) 寻

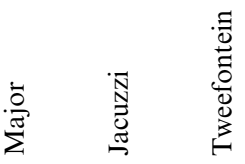



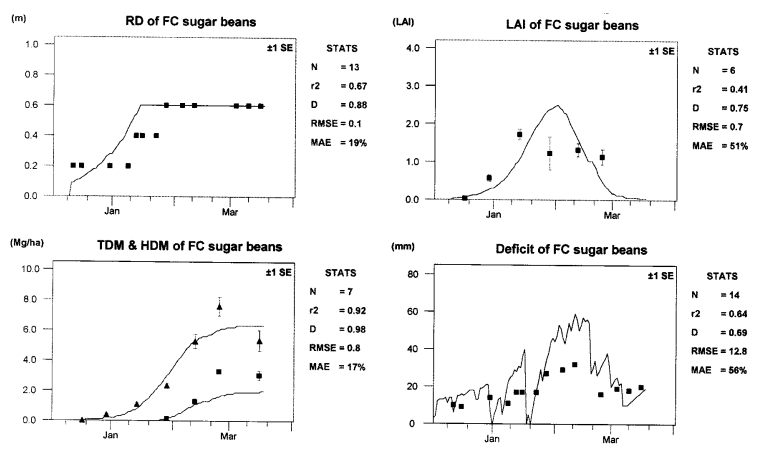

Fig. 1. Measured (symbols) and simulated (line) root depth (RD), leaf area index (LAI), top dry matter (TDM) and harvestable dry matter production (HDM), as well as soil water deficit to field capacity for sugar beans (field capacity strategy, Major field, 1997-1998 season)). The parameters of the statistical analysis of measured and simulated data are number of observations $(N)$, coefficient of determination $\left(r^{2}\right)$ Willmott (1982) index of agreement $(D)$, root mean square error (R.M.S.E.) and mean absolute error (M.A.E.). Vertical bars are \pm 1 standard error (S.E.) of the measurement.

of a model. Root depth was estimated from soilwater measurements with the NWM. It was assumed to be equal to the depth, at which $90 \%$ of soil water depletion occurred after dry spells. The
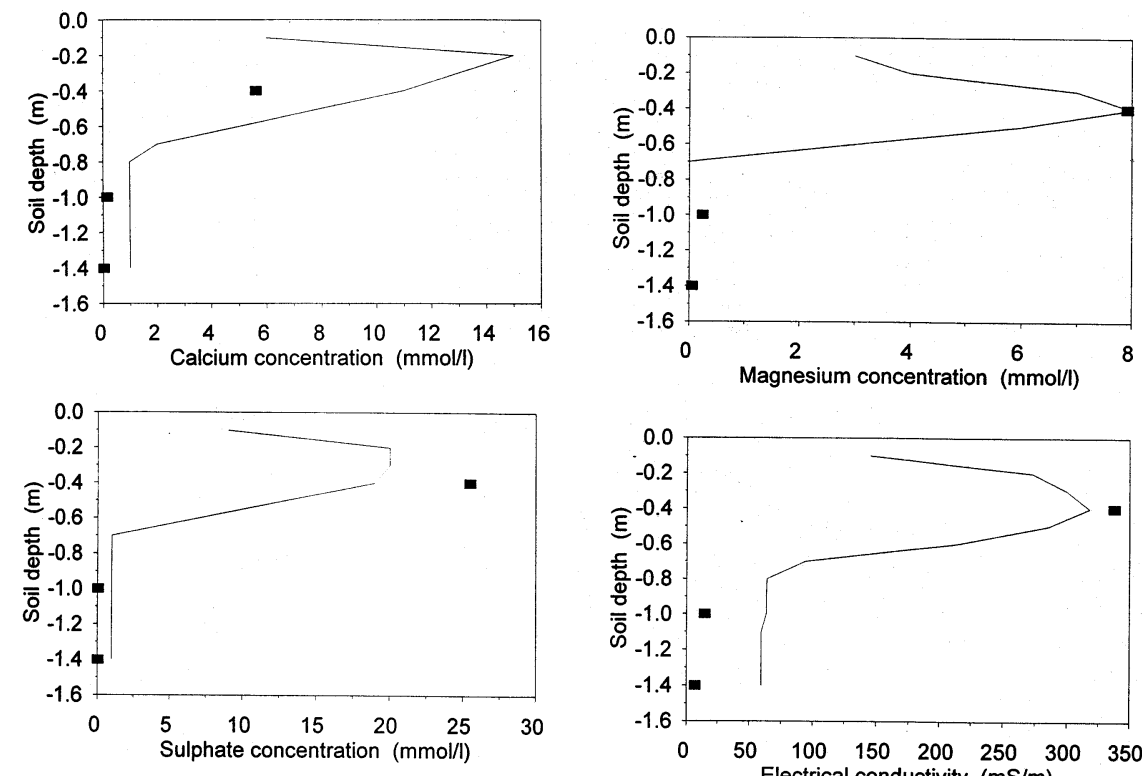

statistical analysis shown in the TDM and HDM graph is only for measured and simulated total above-ground dry matter production. On some occasions after heavy rains, the soil-water deficit to field capacity was negative, as the sandstone/ plinthic layer limited deep percolation. Due to the physiological requirements of sugar beans, the soil profile was partially dried out before harvest.

Fig. 2 presents measured and simulated values of $\mathrm{Ca}^{2+}, \mathrm{Mg}^{2+}$, and $\mathrm{SO}_{4}^{2-}$ concentration, as well as electrical conductivity of the soil solution at the end of the growing season (18 March 1998). Measured data were obtained from laboratory analyses carried out on soil-water samples extracted with the ceramic cup samplers. The model prediction of soil salinity parameters was reasonable. The concentration of $\mathrm{Ca}^{2+}$ was distinctly overestimated at $40 \mathrm{~cm}$ depth compared with $\mathrm{Mg}^{2+}$. This was probably due to preferential adsorption of $\mathrm{Ca}^{2+}$ which is not simulated by SWB. Simulations could be further improved by taking the following into account (i) spatial variability of salts (no replication of soilwater samples was taken); (ii) variations in irrigation water quality; (iii) upward salt movement, and (iv) cation exchange reactions.

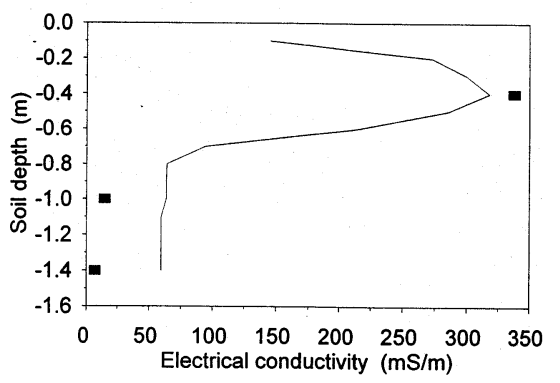

Fig. 2. Measured (symbols) and simulated (line) $\mathrm{Ca}^{2+}, \mathrm{Mg}^{2+}$ and $\mathrm{SO}_{4}^{2-}$ concentration, as well as electrical conductivity of the soil solution in the soil profile of Major field (field capacity strategy) on 18 March, 1998. 


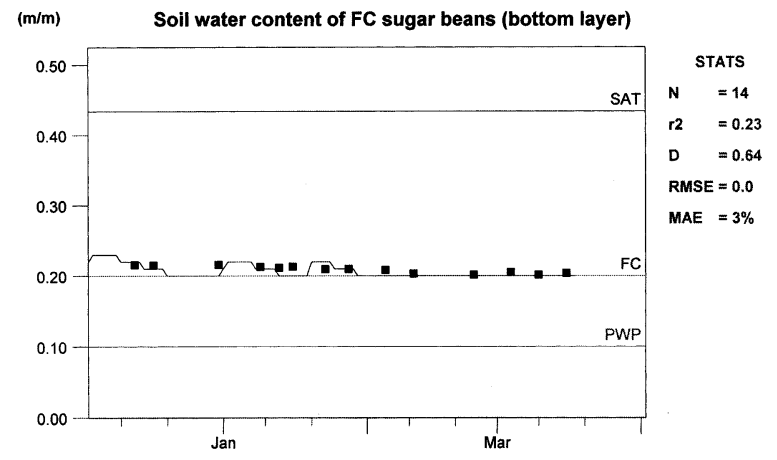

Fig. 3. Measured (symbols) and simulated (line) volumetric soil-water content in the bottom layer $(1-1.1 \mathrm{~m})$ of the field capacity strategy at Major field (1997-1998 season). Saturation (SAT), field capacity (FC) and permanent wilting point (PWP) water contents are also shown. The parameters of the statistical analysis of measured and simulated data are number of observations $(N)$, coefficient of determination $\left(r^{2}\right)$, Willmott (1982) index of agreement $(D)$, root mean square error (R.M.S.E.) and mean absolute error (M.A.E.).

Simulated values of the water and salt balance components for each crop, field and irrigation strategy are summarized in Tables 2 and 3. Variable amounts of rain were measured in the same field at intensive monitoring sites located a few $100 \mathrm{~m}$ from each other. In particular, the LF treatment of sugar beans at Major was located in the area planted on 27 November 1997 and recorded much higher seasonal rainfall compared with the other treatments in the same field (Table 2 ), as these were located in the area planted on 3 December 1997. Different water use efficiencies of sugar beans were used as crop input in the simulations. The vapor deficit corrected transpirationbiomass coefficient (Tanner and Sinclair, 1983) was $6 \mathrm{~Pa}$ for the crop grown at Major, 4.5 $\mathrm{Pa}$ for Tweefontein, and $3 \mathrm{~Pa}$ for Jacuzzi. This was necessary due to the poor stand of the crop at Tweefontein and, in particular, Jacuzzi. Surface and sub-surface run-off of water and salts was assumed to be zero. Due to the presence of the sandstone/plinthic or spoil layer, a maximum drainage rate was estimated for each treatment from soil-water measurements with the NWM. Fig. 3 shows the volumetric soil water content in the bottom layer $(1-1.1 \mathrm{~m})$ of the FC treatment of sugar beans at Major. Both measured and simulated values were above field capacity for most of the season. The maximum drainage rate was estimated to be $0.2 \mathrm{~mm}$ per day for this treatment. This value provided the best statistical fit between measured and simulated data. Much wetter soil profiles were measured and simulated for the LF strategy, where water tables occurred at all three sites. The negative sign of change in soil-water storage (Table 2) indicates that soil water was extracted by the crops during the growing season. This was particularly evident for wheat which requires a prolonged drying off period before harvest.

The SWB model predicted an increase in salinity levels particularly in the top soil layers, and small amounts of gypsum precipitated during the rainy summer 1997-1998 season (Table 3). Considerable amounts of gypsum were estimated to have precipitated in the soil profile during the dry winter season. Due to the presence of the sandstone/plinthic or spoil layer preventing deep percolation, the amount of salts leached out of the soil profile was predicted to be small for all crops and treatments. Fertilizer input was assumed to be a negligible component of the salt balance, as fertilizations were carefully planned and managed.

\subsection{Long-term simulation}

Good agreement between measured and simulated data in the short-term, gives confidence that the SWB model can be used to predict the longterm water and salt balance. A 50-year simulation was carried out for a sugar beans-wheat rotation with soil input data settings for Major field and the FC strategy. Planting dates were 1 December for sugar beans and 15 June for wheat each year. Long-term weather records were generated using the CLIMGEN weather data generator of G.S. Campbell (Washington State University), a modified version of WGEN (Richardson and Wright, 1984). CLIMGEN was assessed at South African sites by Clemence (1997), who showed the estimations to be quite satisfactory. Twenty years of historic weather data (daily maximum and minimum temperature, and rainfall) were collected for the meteorological station in Bethal, the nearest to Kleinkopje Colliery with a reasonably 


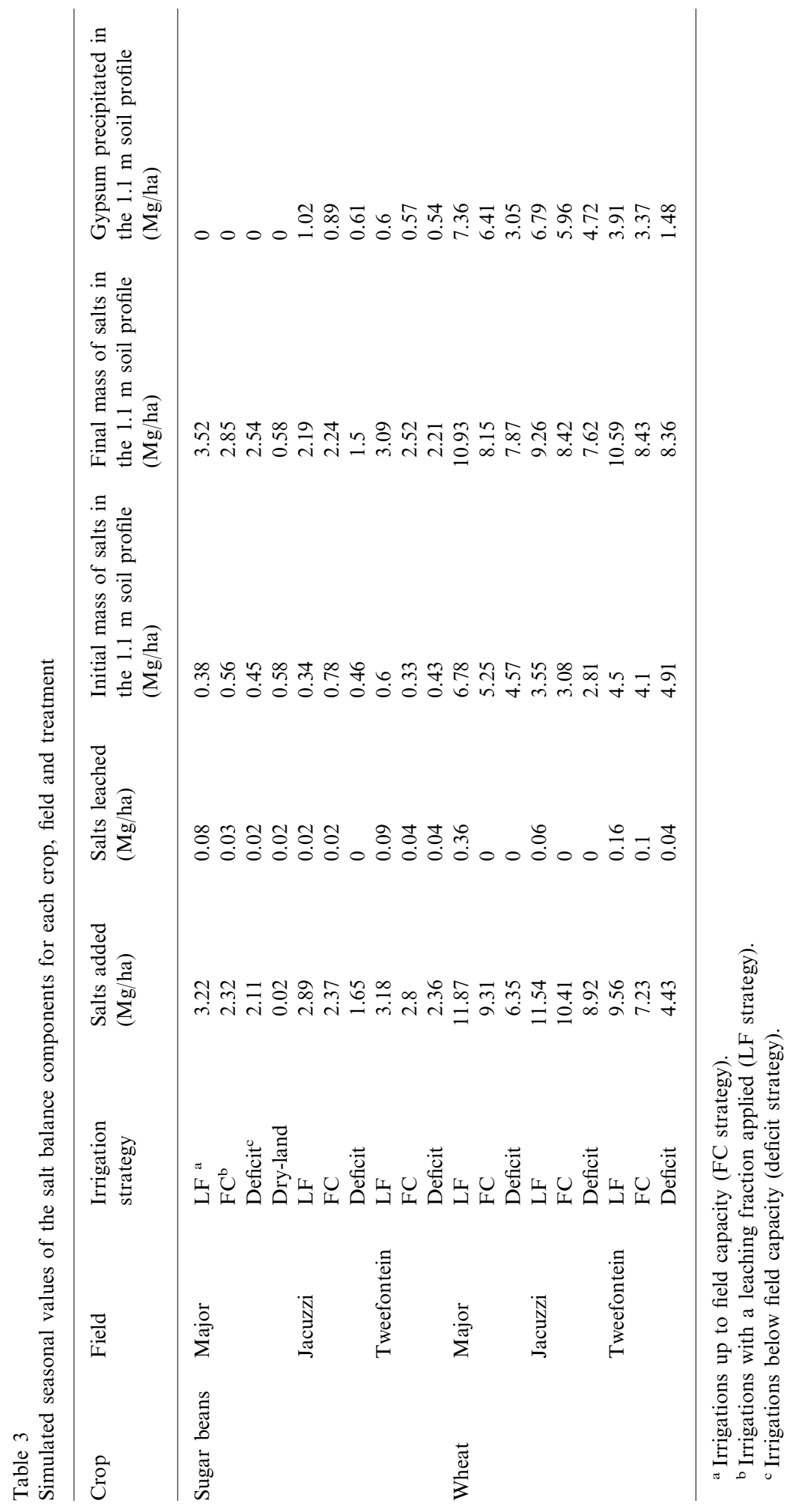


long record of data, and used as input in the weather data generator. It was assumed that similar weather conditions to those in Bethal would occur in the area surrounding Kleinkopje Colliery. Irrigations were simulated on days when the soil-water deficit was calculated to be equal to, or greater than, $20 \mathrm{~mm}$ during both cropping and fallow periods.

The 50-year simulation run gave valuable estimates of the volume of water that could be used and mass of salts that could be precipitated (Table 4). The lengths of fallow periods between crops varied from year to year as harvesting was simulated when the crops reached thermal time requirements for maturity. Fallow periods generally lasted 2 weeks before planting sugar beans and 10 weeks before planting wheat. Variability in evapotranspiration was due to annual rain distribution and variability in the soil evaporation component, as well as the length of the growing season which affected crop transpiration and irrigations applied. For this simulation, it was assumed that the problem of restricted drainage is solved. The total mass of salts leached can be

Table 4

Simulated values of water and salt balance components and S.D., for 50 years of sugar beans-wheat rotation irrigation to field capacity with gypsiferous mine water

\begin{tabular}{lc}
\hline Water and salt balance component & Simulated value \\
\hline Evapotranspiration (mm per year) & $926 \pm 38$ \\
Rainfall (mm per year) & $695 \pm 138$ \\
Irrigation (mm per year) & $536 \pm 55$ \\
Canopy interception of water & $45 \pm 4.6$ \\
$\quad$ (mm per year) & $260 \pm 87$ \\
Drainage (mm per year) & 0 \\
Change in soil water storage & \\
$\quad$ (mm) & $15.30 \pm 1.54$ \\
Added salts $(\mathrm{Mg} /$ ha per year) & $10.38 \pm 3.15$ \\
Leached salts $(\mathrm{Mg} /$ ha per year) & $4.42 \pm 2.38$ \\
Precipitated CaSO $(\mathrm{Mg} /$ ha per year) & \\
Canopy interception of salts $(\mathrm{Mg} / \mathrm{ha}$ per & $0.31 \pm 0.02$ \\
$\quad$ year) & \\
Change in salt content in the soil & 9.5 \\
profile $(\mathrm{Mg} / \mathrm{ha}$ ) & \\
TDS a at $0.1-0.2 \mathrm{~m}$ soil depth $(\mathrm{g} / \mathrm{l})$ & $0.1-5.3$ \\
TDS at $1-1.1 \mathrm{~m}$ soil depth (g/l) & $2.7-8.6$ \\
Maximum $\mathrm{TDS}$ in drained water (g/l) & 8.0 \\
\hline
\end{tabular}

a Total dissolved salts. determined from the quality and quantity of the leachate integrated over the irrigated area. Except for the surface layer, it was predicted that $\mathrm{CaSO}_{4}$ would precipitate mostly in the top soil layers, where the soil solution becomes increasingly concentrated due to water uptake by plants. Canopy interception of salts was estimated to be a minor component of the salt balance, whilst an increase in total salt content in the soil profile was predicted. The SWB model has a multi-layer soil component so that salt concentration in the soil solution of the various layers can be predicted over time. Total dissolved salts (TDS) in the soil solution are expected to increase during the dry winters, whilst a decrease in soil salinity is to be expected during the rainy summer seasons. More concentrated soil solutions during dry periods should cause less favourable conditions for crop growth. Predicted TDS values were strongly affected by the occurrence of rainfall, and did not show any particular trend during the 50-year simulation. Higher TDS values were predicted to occur at depths below the root system, where salts are flushed by irrigation water and rainfall. The SWB model keeps track of the amount and quality of drainage water. Drainage water quality was highly dependent on rainfall and salt dynamics in the soil profile. TDS in drained water peaked at around $8 \mathrm{~g} / \mathrm{l}$, equivalent to a solution electrical conductivity of about $1000 \mathrm{mS} / \mathrm{m}$.

\section{Discussion}

Considerable increases in yield of irrigated sugar beans and wheat were obtained under irrigation with gypsiferous mine water, compared with rainfed cropping. No symptoms of foliar injury due to overhead irrigation with gypsiferous water were observed. Yield of summer crops could be improved with a suitable drainage system preventing water logging in specific areas of the fields. A spatial variability study and a 2-D model are recommended to accurately predict crop growth and water use, as well as the water and salt balance for certain areas of the fields.

Statistical analyses of measured and simulated data indicated that the SWB model predicted crop 
growth, as well as the water and salt balance reasonably well. According to the long-term simulation for a sugar beans-wheat rotation, irrigation with gypsiferous mine water is not expected to cause an unacceptable salinity build-up in the soil. Substantial volumes of water can be used and quantities of salt disposed of through irrigation. This can assist the planning of the required area to be irrigated, should this be deemed to be a feasible option for utilizing such water. The soil appears to act as an effective salt sink, with large quantities of gypsum ( $\approx 220 \mathrm{Mg} / \mathrm{ha}$ ) being precipitated in 50 years. Possible clogging of soil pores with precipitated gypsum is not seen as a serious problem as it is expected to occur in the top soil layers where the soil solution tends to concentrate due to crop water uptake. The accompanying cultivation should open up the soil structure, thereby, alleviating the problem. Different results can be expected for a different cropping system, irrigation water quality and irrigation strategy (Annandale et al., 1996b). Pasture crops irrigated at high frequency and having a transpiring canopy for most of the year, are expected to use more water than field crops. The choice of the cropping system, however, will also depend on economics and plant nutritional aspects.

The SWB model should give a good first approximation of the long-term water and salt balance and is, therefore, a useful tool in assessing the sustainability of irrigation with gypsiferous water. One should, however, be aware of the limitations of such soil-water balance models. Textural discontinuities and impermeable layers have marked effects on water movement, and this can only be reasonably described by a finite-difference model which moves water according to Darcy's law (i.e. using water potential and hydraulic conductivity). Simulations of the effect of pore clogging on hydraulic conductivity would also increase the reliability of the finite-difference simulations. Another disadvantage of the cascading model is that upward flow of salts and water is not simulated. This could be important especially if, a high or perched water table is present. Preferential flow (water flow through cracks and macropores) can also be an important contributor to water and solute redistribution under some conditions. It is unlikely, however, to be critical in a cultivated field system. Cation exchange, the effects of soil $\mathrm{pH}$ and $\mathrm{Al}$ on gypsum precipitation, as well as the accumulation of heavy metals in the soil profile could also be modeled with SWB. This would, however, require more input parameters. It would be of significant benefit for the further detailed validation of the long-term predictive model, if the current evaluations could continue for a number of years. It would also be of benefit, if similar trials could be initiated at a number of different sites, with differing water qualities, weather and soil conditions.

\section{Acknowledgements}

The authors wish to acknowledge the Water Research Commission (Pretoria, South Africa), the National Research Foundation (Pretoria, South Africa), the Department of Trade and Industry (Pretoria, South Africa), and the Chamber of Mines (Johannesburg, South Africa) for funding; Kleinkopje Colliery, Anglo Coal, for capital installation and operation of the trials; and Amfarms (Clewer, South Africa) who were responsible for crop management.

\section{References}

Annandale, J.G., Benadé, N., Van Der Westhuizen, A.J., Campbell, G.S., 1996a. The SWB (Soil Water Balance) irrigation scheduling model. Proceedings of the International Conference on Evapotranspiration and Irrigation Scheduling, San Antonio, Texas, USA, pp. 944-949.

Annandale, J.G., Jovanovic, N.Z. Benadé, N., 1996b. Modelling the Long-Term Effect of Irrigation with Gypsiferous Water on Soil and Water Resources. Report to the Coal Division of Anglo American Corporation of South Africa Ltd. 20 pp.

Barnard, R.O., Rethman, N.F.G., Annandale, J.G., Mentz, W., Jovanovic, N.Z., 1998. The Screening of Crop, Pasture and Wetland Species for Tolerance of Polluted Water Originating in Coal Mines. Water Research Commission Rep. No. 582/1/98, Pretoria, South Africa.

Campbell, G.S., 1985. Soil Physics with Basic. Elsevier Science, Amsterdam, 150 pp.

Campbell, G.S., Diaz, R., 1988. Simplified soil-water balance models to predict crop transpiration. In: Bidinger, F.R., Johansen, C. (Eds.), Drought Research Priorities for the Dryland Tropics. ICRISAT, India, pp. 15-26. 
Campbell, G.S., Norman, J.M., 1998. An Introduction to Environmental Biophysics, second ed. Springer, New York.

Clemence, B.S.E., 1997. A brief assessment of a weather data generator (CLIMGEN) at South African sites. Water SA 23 (3), 271-274.

De Jager, J.M., 1994. Accuracy of vegetation evaporation ratio formulae for estimating final wheat yield. Water SA 20 (4), 307-315.

Du Plessis, H.M., 1983. Using lime treated acid mine water for irrigation. Water Sci. Technol. 15, 145-154.

FAO, 1998. World reference base for soil resources. World Soil Resources Report No. 84, Food and Agriculture Organization of the United Nations, Rome, Italy.

Jovanovic, N.Z., Annandale, J.G., 1998. Soil and aerial environment affects crop salt tolerance — a modelling study. Appl. Plant Sci. 12 (2), 39-42.

Jovanovic, N.Z., Barnard, R.O., Rethman, N.F.G., Annandale, J.G., 1998. Crops can be irrigated with lime-treated acid mine drainage. Water SA 24 (2), 113-122.

Jovanovic, N.Z., Annandale, J.G., Mhlauli, N.C., 1999. Field water balance and SWB parameter determination of six winter vegetable species. Water SA 25 (2), 191-196.

Maas, E.V., 1986. Salt tolerance in plants. Appl. Agric. Res. 1 (1), 12-26.

Monteith, J.L., 1977. Climate and efficiency of crop production in Britain. Philos. Trans. R. Soc. London B 281, 277-294.

Pulles, W., Howie, D., Otto, D., Easton, J., 1995. A Manual on Mine Water Treatment and Management in South Africa. Water Research Commission Rep. No. TT 80/96, Pretoria, South Africa.
Pulles, W., Heath, R., Howard, M., 1996. A Manual to Assess and Manage the Impact of Gold Mining Operations on the Surface Water Environment. Water Research Commission Rep. No TT 79/96, Pretoria, South Africa.

Richardson, C.W., Wright, D.A., 1984. WGEN: A model for generating daily weather variables. US Department of Agriculture, Agricultural Research Service.

Ritchie, J.T., 1972. Model for predicting evaporation from a row crop with incomplete cover. Water Resour. Res. 8, 1204-1213.

Robbins, C.H., 1991. Solute transport and reactions in salt-affected soils. In: Hanks, R.J., Ritchie, J.T. (Eds), Modeling Plant and Soil Systems. Agronomy Monograph no. 31, ASA-CSSA-SSSA, Madison, WI, USA, pp. 365-395.

Smith, M., Allen, R.G., Pereira, L.S., 1996. Revised FAO methodology for crop water requirements. Proceedings of the International Conference on Evapotranspiration and Irrigation Scheduling, San Antonio, TX, USA, pp. 133140.

Soil Classification Working Group, 1991. Soil classification. A taxonomic system for South Africa. Dept of Agric. Development, Pretoria, South Africa.

Tanner, C.B. Sinclair, T.R., 1983. Efficient water use in crop production: research or re-search? In: Taylor, H.M., Jordan, W.R., Sinclair, T.R. (Eds), Limitations to Efficient Water Use in Crop Production. ASA-CSSA-SSSA, Madison, WI, USA, pp. 1-27.

Van Staden, C.M., 1979. How ERPM uses lime to solve unique underground water problem. Coal, Gold Base Miner. Southern Africa 27 (5), 100-109.

Willmott, C.J., 1982. Some comments on the evaluation of model performance. Bull. Am. Met. Soc. 63, 1309-1313. 